\title{
Impact of composts with the participation of municipal sewage sludge on the content of the total forms of copper, manganese and zinc in soil
}

\author{
Ewa Krzywy-Gawrońska \\ West Pomeranian University of Technology, Szczecin, Department of Environmental Chemistry, ul. Stowackiego 17, \\ 71-434 Szczecin, Poland, e-mail: Ewa.Krzywy-Gawronska@zut.edu.pl
}

Pot experiment was conducted in the hall of vegetation at University of Agriculture in Szczecin over the years $2001-2003$ on the soil of IVa complex of agriculture usefulness (very good rye) numbered among loamy sand as regards to the granulometric composition. The composts used in the experiment were after 8 months of decomposition. There was more nitrogen and phosphorus in the composts in comparison with potassium. In the pattern of the research the doses of composts, corresponding with 100,200 and $300 \mathrm{~kg} \mathrm{~N} \cdot \mathrm{ha}^{-1}$, i.e. 0.63 ; 0.99 and $0.126 \mathrm{~g} \mathrm{~N}$ pot were used. The experiment was conducted in four repetitions. In 2001 spring rape Licomos variety was the test plant, in 2002 it was the spring triticale Wanad variety and in 2003 oats Polar variety. In the second and third year of the research of the soil there was $0.475 \mathrm{~g} \mathrm{~N}, 0.137 \mathrm{~g} \mathrm{P}$ and $0.315 \mathrm{~g} \mathrm{~K}$ applied into every pot. It corresponded with the doses of $150 \mathrm{~kg} \mathrm{~N} \cdot \mathrm{ha}^{-1}, 43.6 \mathrm{P} \cdot \mathrm{ha}^{-1}$ and $100 \mathrm{~kg} \mathrm{~K} \cdot \mathrm{ha}^{-1}$. Mineral fertilizers were used in the form of urea, double superphosphate, $60 \%$ potassium salt.

The obtained results of the research indicate that the content of the total forms of copper, manganese and zinc in the composts, with the participation of sewage sludge fulfilled the norms concerning the organic fertilizers.

Over the years, since the time of an application into the soil the composts with the participation of municipal sewage sludge, the content of the total forms of copper, manganese and zinc has decreased. It was caused by the uptake of these micronutrients by plants.

Keywords: municipal sewage sludge, compost, soil, copper, manganese, zinc.

\section{INTRODUCTION}

High prices of the mineral fertilizers, decrease of the production of the natural fertilizers and changes in the structure of crops to profit the acceleration of the acreage of the cultivation of crops and the plants designed for the energetic purposes (biofuel) cause an occurrence of adverse balance of the organic substances and nutrients in the soil of Poland.

That situation was the reason to search for new, cheaper and safe for the environment, sources of the organic substance and nutrients, there on the municipal sewage sludge. The restrictions in using municipal sewage sludge for the agricultural purpose can be caused by an excess of heavy metals, pathogenic germs, parasites and their lively balls. Therefore municipal sewage sludge should be subject of the stabilization and hygienization process. One of the more popular ways of the recovery of the properties of the municipal sewage sludge is composting $2,3,4,6,7$. Composting of the municipal sewage sludge can be performed with different components. In this way there is less content of heavy metals in the municipal sewage sludge fall on the unit of the mass of the organic fertilizer.

Some of the heavy metals, such as copper, manganese and zinc in the specific doses are necessary for the proper rise and growth of the plants. Too big amount of these elements in the fertilizers and next in the soil leads to the plants taking them in excessive quantities. In this situation the crops and their quality reduce.
The aim of the conducted study was to define the amount of the total forms of copper, manganese and zinc in produced composts with an addition of municipal sewage sludge and their influence on the content of these elements in the soil within 3 years of the experiment.

\section{MATERIAL AND METHODS}

To realize the purpose of the study over the years of $2001-2003$ the vegetative-pot experiment was performed on the soil of IVa complex of agriculture usefulness (very good rye) numbered among loamy sand with reference to the granulometric composition. There are some fertility indicators of the soil used in the experiment in Tables 1 and 2 .

The soil used in the experiment was slightly acid. The affluence of phosphorus, potassium and magnesium in available forms was average, whereas that of sulphur low.

The content of the total forms of copper, manganese and zinc in the soil used in the experiment was average ${ }^{1}$.

The composts produced from the municipal sewage sludge from the sewage treatment plants in Stargard Szczeciński were used in the experiment. First, the mate-

Table 2. The content of the total forms of copper, manganese and zinc in the soil before setting up the experiment. Data in $\mathrm{mg} \cdot \mathrm{kg}^{-1} \mathrm{~d} . \mathrm{m}$. of the soil

\begin{tabular}{|c|c|c|}
\hline Copper & Manganese & Zinc \\
\hline 5.50 & 371 & 46.8 \\
\hline
\end{tabular}

Table 1. Some fertility indicators of the soil used in the experiment

\begin{tabular}{|c|c|c|c|c|c|c|c|c|c|c|c|c|}
\hline \multirow{2}{*}{$\begin{array}{c}\mathrm{pH} \\
\mathrm{mol} \cdot \mathrm{dm}^{-3} \\
\mathrm{KCl}\end{array}$} & \multirow{2}{*}{$\begin{array}{l}\text { C org. } \\
{\left[\mathrm{g} \cdot \mathrm{kg}^{-1}\right]}\end{array}$} & \multicolumn{6}{|c|}{ Total content $\left[\mathrm{g} \cdot \mathrm{kg}^{-1}\right]$} & \multirow{2}{*}{$\mathrm{C}: \mathrm{N}$} & \multicolumn{4}{|c|}{ Available forms $\left[\mathrm{mg} \cdot \mathrm{kg}^{-1}\right]$} \\
\hline & & $\mathrm{N}$ & $\mathrm{P}$ & K & $\mathrm{Ca}$ & $\mathrm{Mg}$ & $S$ & & $P$ & K & $\mathrm{Mg}$ & S \\
\hline 6.00 & 12.2 & 1.05 & 1.53 & 2.85 & 2.51 & 0.46 & 0.15 & 11.6 & 64.5 & 123.0 & 48.4 & 4.12 \\
\hline
\end{tabular}


Table 3. Chemical characterization of the composts after 8 months of decomposition

\begin{tabular}{|c|c|c|c|c|c|c|}
\hline \multirow{2}{*}{ Kind of analysis } & \multicolumn{6}{|c|}{ Type of composts* } \\
\hline & $1^{*}$ & $2^{*}$ & $3^{*}$ & $4^{*}$ & $5^{*}$ & $6^{*}$ \\
\hline$\%$ dry matter & 18.7 & 18.6 & 18.7 & 18.9 & 18.4 & 18.8 \\
\hline$(\mathrm{pH})$; reaction $(\mathrm{pH})$ & 7.70 & 7.40 & 7.40 & 7.50 & 7.20 & 7.50 \\
\hline \multicolumn{7}{|c|}{ Content in $\mathrm{g} \cdot \mathrm{kg}^{-1}$} \\
\hline organic C & 355 & 371 & 345 & 310 & 315 & 308 \\
\hline total N & 36.4 & 33.8 & 37.7 & 36.7 & 36.0 & 35.5 \\
\hline $\mathrm{C}: \mathrm{N}$ & 9.75 & 10.97 & 9.15 & 8.45 & 8.72 & 8.68 \\
\hline total P & 23.4 & 21.4 & 22.4 & 22.2 & 22.9 & 21.7 \\
\hline total K & 6.40 & 6.50 & 6.80 & 6.70 & 6.80 & 7.20 \\
\hline total $\mathrm{Ca}$ & 3.90 & 3.80 & 4.00 & 4.20 & 4.10 & 4.90 \\
\hline total $\mathrm{Mg}$ & 26.5 & 25.5 & 25.2 & 25.2 & 24.9 & 25.6 \\
\hline total S & 5.50 & 5.30 & 5.0 & 5.30 & 5.00 & 5.00 \\
\hline \multicolumn{7}{|c|}{ Content in $\mathrm{mg} \mathrm{kg}^{-1}$} \\
\hline total $\mathrm{Cu}$ & 119 & 126 & 128 & 120 & 121 & 120 \\
\hline total $\mathrm{Mn}$ & 249 & 239 & 240 & 259 & 249 & 251 \\
\hline total Zn & 784 & 754 & 748 & 792 & 770 & 753 \\
\hline
\end{tabular}

*Explanation of the types of composts in converting into dry mass (numbers $1-6)$ : compost 1 - municipal sewage sludge (70\%) and city green waste $(30 \%)$, compost 2 - municipal sewage sludge $(70 \%)$ and rye straw $(30 \%)$, compost 3 - municipal sewage sludge $(70 \%)$, city green waste $(15 \%)$ and rye straw $(15 \%)$, compost 4 - municipal sewage sludge $(70 \%)$, city green waste $(20 \%)$ and ash of hard coal $(10 \%)$, compost $5-$ municipal sewage sludge $(70 \%)$, rye straw $(20 \%)$, and ash of hard coal $(10 \%)$, compost 6 - municipal sewage sludge $(70 \%)$, city green waste $(10 \%)$, rye straw $(10 \%)$ and ash of hard coal $(10 \%)$

rial was mixed with the structural components and then it was subjected to a composting process for 8 months. A detailed participation of each component in converting into the dry mass and the chemical composition of the composts were presented in Table 3 . The composts contained distinctly more nitrogen and phosphorus in comparison with potassium. It resulted in the chemical composition of the municipal sewage sludge. Addition of the structural components did not further influence the formation of the content of potassium in each compost. The compost from the municipal sewage sludge $(70 \%)$ and rye straw $(30 \%)$ were characterized most by organic coal and the widest ratio $\mathrm{C}: \mathrm{N}$.

In the pattern three doses of composts that corresponded to 200,300 and $400 \mathrm{~kg} \mathrm{~N} \cdot \mathrm{ha}^{-1}$, that is $0.63 ; 0.99$ and $0.126 \mathrm{~g} \mathrm{~N} \cdot$ pot were taken into consideration. The experiment was conducted in the pots on the capacity of $9 \mathrm{~kg}$ of the soil, in four repetitions.

Appropriated doses of composts were put into the pots with the soil in spring 2001. These composts were mixed with the soil to the depth of $10-12 \mathrm{~cm}$. In view of a small content of potassium in the composts (Table 3) in 2001 water solution of potassium salt $60 \%$ was additionally put into the soil. Water solution of potassium salt was put in such amount so that in each manurial variant of the experiment the $\mathrm{N}$ : $\mathrm{K}$ ratio was 1.0: 0.86 in the used fertilizers. The counted doses of the water solution of potassium salt $60 \%$ were put into the soil in the pots. The solution was mixed with the soil to the depth of $5-6 \mathrm{~cm}$. The tested plants were spring rape type Licosmos (2001 year), spring triticale type Wanad (2002 year), oat type Polar (2003 year). In the second year of the experiment (2002) water solution of macroelements: $0.475 \mathrm{~g} \mathrm{~N} \cdot$ pot in the form of urea, $0.137 \mathrm{~g}$ P.pot in the form of double superphosphate and $0.315 \mathrm{~g} \mathrm{~K} \cdot$ pot in the form of salt potassium, were put into all pots. In the third year of the experiment water solution $0.315 \mathrm{~g} \mathrm{~N}$.pot in the form of urea, $0.109 \mathrm{~g}$ P.pot in the form of double superphosphate and $0.262 \mathrm{~g} \mathrm{~K} \cdot$ pot in the form of salt potassium $60 \%$ were put into all pots. The water solution of urea was divided into two parts and it was used in $50 \%$ before sowing of the spring rape, spring triticale and oat and in 50\% 4 weeks after the rise of spring rape as well as in the phase of shooting of the stalk of the corns. The soil humidity was kept at the $60 \%$ level of full water capacity through the whole time of vegetation of the tested plants. The soil was sprinkled with the redistill water. After the inning of the tested plants the samples of the soil were taken from each pot. The average samples for each manurial variant were obtained after the mixing of the individual samples.

The content of the total forms of copper, manganese and zinc was indicated in the samples of the soil using the OSTROWSKA method.

\section{DISCUSSION}

The obtained results of the study are presented in tables 4 and 5. The average content of the total forms of copper, manganese and zinc in the soil, after using the composts with the participation of municipal sewage sludge, is presented in Table 4. The average content of the total forms of the tested elements in the soil, which was obtained under the influence of increasing the doses of the composts with the participation of municipal sewage sludge, is presented in Table 5.

In the control variant (without the composts) the content of the total forms of copper, manganese and zinc in the soil decreased in comparison with the initial data (Table 2 and 4). That effect is caused by taking the tested elements by the tested plants during the experiment.

The composts with the participation of the municipal sewage sludge, which had been put into the soil, caused a significant increase of the content of the total forms of copper, manganese, zinc in comparison with the soil from the control variant. Over the years of the studies the content of the total forms of copper, manganese and zinc in the soil was essentially decreased. This situation is relative to taking these elements by the crops.

In the control variant (without the composts) there were essentially fewer total forms of copper, manganese and 
Table 4. The impact of the composts with the participation of municipal sewage sludge on the content of the total forms of manganese, copper and zinc in soil. Data in $\mathrm{mg} \cdot \mathrm{kg}^{-1} \mathrm{~d} . \mathrm{m}$. of the soil

\begin{tabular}{|c|c|c|c|c|c|c|c|c|c|}
\hline \multirow[b]{2}{*}{$\begin{array}{l}\text { Years of } \\
\text { research }\end{array}$} & \multicolumn{8}{|c|}{ Compost } & \multirow[b]{2}{*}{$\begin{array}{l}\text { Mean of } \\
\text { composts }\end{array}$} \\
\hline & $\begin{array}{l}\text { Control } \\
\text { variant } \\
\text { without } \\
\text { compost }\end{array}$ & $\begin{array}{c}\text { Compost } \\
1^{*}\end{array}$ & $\begin{array}{c}\text { Compost } \\
2^{*}\end{array}$ & $\begin{array}{c}\text { Compost } \\
3^{*}\end{array}$ & $\begin{array}{c}\text { Compost } \\
4^{*}\end{array}$ & $\begin{array}{c}\text { Compost } \\
5^{\star}\end{array}$ & $\begin{array}{l}\text { Com- } \\
\text { post } \\
6^{*}\end{array}$ & $\begin{array}{c}\text { Com- } \\
\text { post } 7 *\end{array}$ & \\
\hline \multicolumn{10}{|c|}{ Copper } \\
\hline 2001 & 4.95 & 5.28 & 5.42 & 5.44 & 5.55 & 5.52 & 5.43 & 5.51 & 5.45 \\
\hline 2002 & 5.00 & 5.08 & 5.53 & 5.46 & 5.63 & 5.48 & 5.52 & 5.52 & 5.46 \\
\hline 2003 & 4.80 & 4.57 & 4.92 & 5.03 & 4.89 & 4.97 & 4.96 & 5.08 & 4.92 \\
\hline Mean & 4.92 & 4.98 & 5.29 & 5.31 & 5.36 & 5.32 & 5.30 & 5.37 & 5.27 \\
\hline \multicolumn{10}{|c|}{$\begin{array}{l}\mathrm{LSD}_{0,005:} \text { dla: } \\
\text { I factor years of study }-0.007 \\
\text { II factor kind of compost }-0.015 \\
\text { Ix II }-0.020\end{array}$} \\
\hline \multicolumn{10}{|c|}{ Manganese } \\
\hline 2001 & 372 & 395 & 390 & 394 & 388 & 390 & 387 & 391 & 391 \\
\hline 2002 & 357 & 383 & 377 & 384 & 382 & 382 & 380 & 381 & 381 \\
\hline 2003 & 360 & 380 & 372 & 380 & 384 & 378 & 369 & 367 & 375 \\
\hline Mean & 363 & 386 & 380 & 386 & 385 & 383 & 379 & 380 & 382 \\
\hline \multicolumn{10}{|c|}{$\begin{array}{l}\text { NIR } 0,005, L D_{0,005:} \text { dla: } \\
\text { I factor year of study }-0.578 \\
\text { II factor kind of compost- } 1.254 \\
\text { Ix II }-1.636\end{array}$} \\
\hline \multicolumn{10}{|c|}{ (1. 1.000} \\
\hline 2001 & 39.8 & 41.3 & 40.7 & 42.0 & 41.6 & 43.1 & 42.8 & 42.9 & 42.1 \\
\hline 2002 & 38.3 & 39.2 & 39.1 & 39.8 & 40.1 & 39.7 & 39.4 & 40.0 & 39.6 \\
\hline 2003 & 36.8 & 36.7 & 37.2 & 37.1 & 37.8 & 37.7 & 37.8 & 37.8 & 37.4 \\
\hline Mean & 38.3 & 39.1 & 39.0 & 39.6 & 39.8 & 40.2 & 40.0 & 40.2 & 39.7 \\
\hline \multicolumn{10}{|c|}{$\begin{array}{l}\text { NIR } 0,005, \mathrm{LSD}_{0,005:} \text { dla: } \\
\text { I factor year of study }-0.026 \\
\text { II factor kind of compost }-0.057 \\
\text { Ix II }-0.074\end{array}$} \\
\hline
\end{tabular}

${ }^{*}$ Composition of composts given under Table 3 .

Table 5. The impact of the doses of the composts with the participation of municipal sewage sludge on the content of the total forms of manganese, copper and zinc in soil. Data in $\mathrm{mg} \cdot \mathrm{kg}^{-1} \mathrm{~d} . \mathrm{m}$. of the soil

\begin{tabular}{|c|c|c|c|c|}
\hline \multirow[b]{2}{*}{ Years of research } & \multicolumn{3}{|c|}{ Doses of composts } & \multirow[b]{2}{*}{ Mean of dose compost } \\
\hline & $\begin{array}{c}\text { I dose } \\
\text { of compost }\end{array}$ & II dose of compost & $\begin{array}{l}\text { Ill dose of } \\
\text { compost }\end{array}$ & \\
\hline \multicolumn{5}{|c|}{ Copper } \\
\hline 2001 & 5.31 & 5.37 & 5.76 & 5.35 \\
\hline 2002 & 5.37 & 5.45 & 5.56 & 5.34 \\
\hline 2003 & 4.76 & 4.92 & 5.06 & 4.88 \\
\hline Mean & 5.15 & 5.25 & 5.46 & 5.19 \\
\hline \multicolumn{5}{|c|}{$\begin{array}{l}\text { NIR }{ }_{0,005}, \mathrm{LSD}_{0,005:} \text { dla: } \\
\text { I factor year of study }-0.015 \\
\text { II factor kind of compost }-0.019 \\
\text { Ix II }-0.030\end{array}$} \\
\hline \multicolumn{5}{|c|}{ Manganese } \\
\hline 2001 & 381 & 391 & 400 & 386 \\
\hline 2002 & 372 & 378 & 392 & 347 \\
\hline 2003 & 365 & 373 & 388 & 371 \\
\hline Mean & 373 & 381 & 393 & 296 \\
\hline \multicolumn{5}{|c|}{$\begin{array}{l}\text { NIR }{ }_{0,005} L_{S S D_{0,005:}} \text { dla: } \\
\text { I factor year of study }-1.035 \\
\text { II factor kind of compost }-1.331 \\
\text { Ix II }-2.070\end{array}$} \\
\hline \multicolumn{5}{|c|}{ Zinc } \\
\hline 2001 & 41.9 & 41.7 & 42.6 & 41.5 \\
\hline 2002 & 38.9 & 39.4 & 40.4 & 39.2 \\
\hline 2003 & 36.9 & 37.4 & 38.0 & 37.3 \\
\hline Mean & 39.2 & 39.5 & 40.3 & 39.3 \\
\hline \multicolumn{5}{|c|}{$\begin{array}{l}\text { NIR } 0,005, L S_{0,005:} \text { dla: } \\
\text { I factor year of study }-0.052 \\
\text { II factor kind of compost }-0.067 \\
\text { Ix II }-0.104\end{array}$} \\
\hline
\end{tabular}


zinc in the soil in comparison with the variants, in which the composts with the participation of the municipal sewage sludge with different structural components were put into the soil.

The soil with the compost from the municipal sewage sludge (70\%) and with an addition of each $10 \%$ of rye straw, wastes from the urban greenery and ash of hard coal contained the most of the total copper. The differences in the impact of each compost on the formation of the content of copper in the soil were essential.

The soil with the composts with the participation of municipal sewage sludge (70\%) and with the addition of rye straw $(30 \%)$ or rye straw $(15 \%)$ and wastes form urban greenery contained the most of manganese. The difference in the impact of these composts on the content of manganese was not essential. The remaining composts essentially decreased the content of total manganese in the soil in comparison with the above.

The soil with the composts with the participation of municipal sewage sludge $(70 \%)$ with addition of rye straw $(20 \%)$ and ash from the stone coal $(10 \%)$ or with the addition of $10 \%$ each of rye straw, wastes from urban greenery and ash of hard coal contained the most of the total zinc. The impact of the remaining composts on the formation of the content of total zinc in the soil was essentially smaller in comparison with the above.

In view of an addition of the same amount of municipal sewage sludge to all composts it can be claimed that the used structural components had an essential influence on the formation of the content of the total forms of copper, manganese and zinc in the soil (Table 4).

Increasing the doses of the composts caused essential increase of the content of the total forms of the tested elements in the soil. The soil with the highest dose of composts, that means $0.126 \mathrm{~g} \mathrm{~N} \cdot$ pot, alias $300 \mathrm{~kg} \mathrm{~N} \cdot \mathrm{ha}^{-1}$ as organic fertilizer contained the most of total forms of copper, manganese and zinc (Table 5). The obtained results show that the used composts with the participation of the municipal sewage sludge can be a source of copper, manganese and zinc in the soil for the crops. The content of the total forms of copper, manganese and zinc in the soil under the influence of the composts with the participation of municipal sewage sludge can be supposed as normal irrespective of their structural components ${ }^{\mathbf{1}, 2}$.

\section{CONCLUSIONS}

1. The tested composts with the participation of the municipal sewage sludge did not contain excessive amount of copper, manganese and zinc.

2. The used composts with the participation of the municipal sewage sludge did not cause excessive concentration of the total forms of copper, manganese and zinc irrespective of the components and quantity of these doses.

3. Over the years, from the time of application into soil the composts with the participation of municipal sewage sludge, the content of the total forms of copper, manganese and zinc has decreased.

\section{LITERATURE CITED}

1. Kabata-Pendias, A. \& Pendias H. (1999). Biotechnology trace elements. PWN Warszawa ss.400 (in Polish).
2. Krzywy, E., Wołoszyk, Cz. \& Iżewska, A. (2000). Fertilizer value municipal sewage sludge. Oddział Szczeciński PTIE: 5 - 58 (in Polish).

3. Krzywy, E., Wołoszyk, Cz. \& Iżewska, A. (2002). Agricultural Production and use of compost from sewage sludge with the addition of various components. Oddział Szczeciński PTIE ss. 39 (in Polish).

4. Oleszkiewicz, J.A. (1998). Economy sludge. Guide decision maker LEM sc. Kraków. ss. 28 4(in Polish).

5. Ostrowska, A., Gawliński, S. \& Szczubiałka, Z. (1991). Methods of analysis and assess properties of soils and plants. IOŚ Warszawa ss.334 (in Polish).

6. Szpadt, R. (1993). Recycling and disposal of sediment from small sewage treatment plant.(in Polish) [In: Waste water and waste management in municipalities], I National Conf. Training, 23-24 September 1993, Poznań: 171 - 185 (in Polish).

7. Urbaniak, M. (1997). Processing and utilization of sludge from wastewater utilities (in Polish). PAN Oddział - Łódź, ss:80. 